\title{
Defining the Geographical and Historical Parameters of This Study
}

... The problem becomes acute when considering the architectural traditions of Georgia. Lying just north of Armenia and bordered on the west by the Black Sea, the architecture of this region offers striking similarities with that of Armenia. The small, centrally-planned structures, with their conical roofs and sculptural decoration, bear close resemblance to those found in Armenia. These visual similarities reflect the continuous contact and interrelations between the two lands, most visible in the marchland areas of Tayk' and Tao, which have defied a precise identification of an Armeno-Georgian border, and where churches often feature bilingual inscriptions. The closeness of the two traditions, both in ecclesiastical architecture and in almost all other architectural genres, encourages the formulation of a Transcaucasian, rather than strictly Armenian study. The abundance of commonalities discourages drawing an overly rigid line between them, as is common in much of the scholarship on the Transcaucasus.

The problem of defining "Armenian" and "Georgian" architecture thus remains, as well as how, when, and why to distinguish between them. In some cases, it seems that the term Transcaucasian is more appropriate. ${ }^{1}$

In an area of research so fraught with Nationalist (with a capital "N") agendas, it seems wise to begin by mentioning the elephant in the room from the outset. In the quotation above Christina Maranci addresses the question of whether or not the way forward is to develop an architectural history of the Transcaucasus rather than insisting on exploring the Georgian and Armenian traditions separately. This is an approach that has since been adopted by Annegret Plontke-

1 pp. 248-249, Maranci, Christina, Medieval Armenian Architecture: Constructions of Race and Nation, Peeters; Leuven, 2001.

(C) EMMA LOOSLEY LEEMING, 2018 | DOI:10.1163/9789004375314_002

This is an open access chapter distributed under the terms of the prevailing CC-BY-NC License at the time of publication. 
Lüning ${ }^{2}$ and is undeniably a sensible direction in which to proceed. Naturally this is an issue that does not affect simply architectural historians, but all who seek to study the history and material culture of the Caucasus, whatever their discipline; although the quotation above is referring to architectural history, we can apply the same arguments for a more inclusive approach to the study of the region across all the humanities and social sciences.

The fact that so few people have taken up the challenge to approach the region with a comprehensively pan-Caucasian attitude can be most clearly explained by considering the political and linguistic complexities not only of the Transcaucasian countries themselves but also the wider Eurasian milieu in which they are embedded. The official date for the end of the Soviet Union is assigned to December 1991, but of course history is rarely that neat and it was some years before the full implications of this dissolution became clear. However, during most of the twentieth century, Transcaucasia was not always easy for academics to access and this is reflected in the scant academic literature, on Georgia in particular, available in languages other than Russian and Georgian. It must be noted at this point that despite the fact that Soviet Armenia was just as difficult for foreign scholars to access as Soviet Georgia, there was more work being undertaken on Armenian subjects throughout the Soviet period in European and North American institutions because of the long-established Armenian diaspora communities who not only celebrated their culture, but also supported their commitment to their ancestral homeland with programmes of philanthropic endeavour endowing museums, cultural centres and academic chairs amongst other activities. ${ }^{3}$ This situation was not (and is not) the case with the corresponding Georgian situation. Unlike their Armenian neighbours the Georgians do not have a large diaspora community. Contemporary Georgians often cheerfully admit that as a people they remain largely within the confines of their homeland and, although Georgia established a significant expatriate community in Paris after the fall of the short-lived Georgian Democratic Republic to the Bolsheviks in February 1921, they do not have an established international network of academics, cultural centres and museums in the same way as their Armenian neighbours.

2 Plontke-Lüning, Annegret, Frühchristliche Architektur In Kaukasien. Die Entwicklung des christlichen Sakralbaus in Lazika, Iberien, Armenien, Albanien und den Grenzregionen vom 4. bis zum 7.Jh., Verlag der Österreichischen Akademie der Wissenschaften; Wien, 2007.

3 Both Oxford and Harvard (for example) have named chairs in Armenian Studies - the Mashtots Chair at Harvard and the Calouste Gulbenkian Chair at Oxford-meaning that there are high-profile appointments and an established tradition of Armenian Studies outside the former Soviet region. 
Naturally the study of Georgian language and history has always been pursued by a small number of scholars and even through the uncertainties of the post-Soviet years academics continued to visit and write on Georgian subjects - with David Braund, Antony Eastmond and Stephen Rapp Jr being three English-language scholars prominent in this regard-but the fact remains that Georgian language and culture still remains relatively understudied outside the boundaries of the country itself. This situation is often linked to the fact that the Georgian language is a member of the Kartvelian group and is not closely related to other linguistic families making it perhaps more difficult to study than other regional languages that fit within the Indo-European or Turkic linguistic families.

It is necessary to highlight these issues here because within this study the regions being examined are limited to those that formed the Roman provinces of Syria, Osrhoene and Mesopotamia, which now equate to modern Syria, Lebanon and parts of southeastern Turkey and western Iraq, and the areas that are approximately analogous to the ancient kingdoms of Lazica (Egrisi) and Iberia (Kartli) which is roughly comparable to contemporary Georgia (including the currently contested regions of Abkhazia/Apkhazeti and South Ossetia/Tskhinvali) (See Map 1). The principal reason for this is, as Maranci so clearly demonstrates in her book, that it is an absolute necessity to have some knowledge of the native languages of the regions under discussion and, having embarked on this project with a grounding in Syriac but needing to acquire a working knowledge of both Georgian and Russian along the way, learning Armenian was just too great a task within the five year span of this research.

Modern western academic life demands regular "outputs" from its researchers and this unfortunately does not grant today's scholars as much time as their forebears to immerse themselves in the process of learning new languages, therefore it is because of my personal limitations that the Armenian material is not comprehensively explored in this volume, although it will be referred to in passing. When faced with the desire to explore the inter-relationships of the different cultures in this complex region I took the perhaps perverse choice to work not from the 'known to the unknown' but rather the 'road less travelled' and elected to begin with the Georgian relationship with Syria precisely because, outside the boundaries of Georgia itself, this subject has received very little attention. ${ }^{4}$ This seemed a gap that it seemed necessary to explore

4 There have naturally been some articles on this subject in European languages—see for example works by Haas and Martin-Hisard on the Syrian Fathers in the bibliography-but 


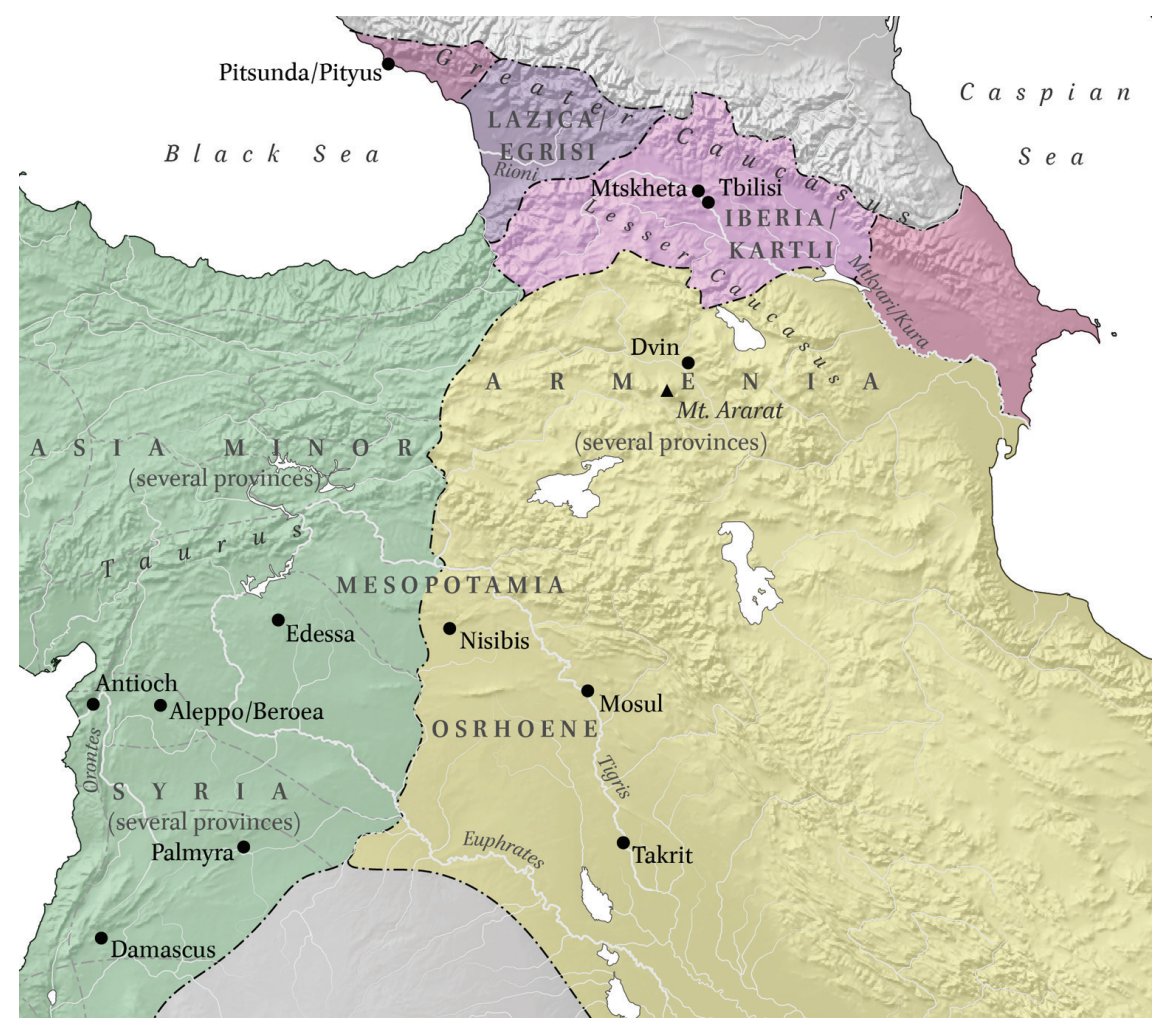

MAP 1 Map of the Levant, Mesopotamia and the Caucasus in the sixth century CE

further, in the hopes that such a study could at the very least, clear up some of the gaps in our knowledge about inter-cultural relationships in late antiquity.

It also needs to be strongly underlined that this volume is intended to be a first step on a path to formulate a clearer understanding of the relationship between Syro-Mesopotamia and the Kingdom of Kartli in late antiquity. There are undoubtedly errors and omissions in the pages that follow, but the aim of the work is to stimulate debate and further research in an undeveloped area of study rather than to provide a definitive account of the subject. Caucasian Studies is a notoriously vicious field rife with nationalist agendas and particu-

outside Georgia itself there have been no book-length studies of Syrian-Georgian interaction and, within Georgia itself as with the few outsiders who have explored this, the subject has been dominated by material devoted to the vitae of the Thirteen (As) Syrian Fathers rather than taking a wider look at the interaction between the two cultures. 
larly vitrolic reactions to opposing points of view. As Rapp pointed out recently "The hyper-politicisation of Caucasian history is the stuff of Promethean legend." ${ }^{5}$

In this charged atmosphere any new or alternative theories are often attacked and dismissed without sufficient considerations of what evidence someone offers for a new interpretation. In the current case the rationale for this study is a simple one; whilst the study of "The Syrian Fathers" has long been an accepted sub-branch of Georgian historical research, there has never been an investigation of the subject by someone coming from a background of Syrian Studies. On the Syrian side there is no awareness at all that the Georgians revere a group of purported Syrian monks in this manner and that disjunction seemed a mystery too interesting to ignore. Nevertheless, during the research for this monograph it became increasingly apparent that in some quarters the conclusions made by any non-Georgian scholar will face particularly extensive scrutiny. ${ }^{6}$ Therefore it must be underlined at the very beginning that as a first step my intention is as much to highlight the lacunae in the historical and archaeological record, as it is to provide any definitive conclusions. In many cases there is a gap in our data that may or may not be filled in the future through archaeological excavation or the discovery of a hitherto unknown literary source. Until that time, this is intended as an attempt to weave together the extant information in a logical manner. It is also intended that future avenues of research will be highlighted as an invitation to open a series of academic conversations - this is very much the opening gambit rather than the final word on the discussions that will follow.

This qualification is necessary not least because of the events that have transpired during the preparation of this work. Whilst this research was conceived and a proposal to the European Research Council was being developed, ${ }^{7}$ a sudden series of events in North Africa and the Middle East precipitated the Syrian civil war meaning that the portions of this work relating to Syria have had to rely on fieldwork undertaken before the outbreak of hostilities. ${ }^{8}$ In addition the

5 RappJr, Stephen H., The Sasanian World through Georgian Eyes: Caucasia and the Iranian Commonwealth in Late Antique Georgian Literature, Ashgate; Farnham, 2014, xv.

6 See the comments relating to this issue in the preface to this volume.

7 This monograph has been made possible thanks to a five year ERC-funded "Starting Grant" within the seventh programme framework.

8 For the purpose of clarity readers should assume that all Syrian fieldwork has effectively been in abeyance since late 2010/early 2011 and therefore, subject to a few notable exceptions such as the Hungarian project at Marqab on the Syrian coast, all publications since that time are reliant on notes from pre-war research. 
fast-moving geo-politics of the former Soviet Union mean that Georgian society is constantly reacting to a series of events that are often beyond their control and this impacts significantly on Georgian identity politics and, by extension, the way that contemporary Georgians interpret their past. ${ }^{9}$ In a more tangible manner it placed a physical limitation on fieldwork in Georgia by preventing travel to the South Ossetia (Tskhinvali) region and Abkhazia (Georgian Abkhazeti) thereby preventing access to approximately $20 \%$ of Georgian territory. ${ }^{10}$

As the observant reader will have noticed, in the paragraph above I talk of exploring the relationship between Iberia/Kartli and Syro-Mesopotamia, but not that of Lazica/Egrisi with Syria. This is because Lazica will be considered in places, but the focus of this monograph will be primarily Kartli, or in modern terms, Georgia east of the Surami Pass and the Likhi mountain range. The reason for this is that Lazica was controlled largely by the Byzantine Empire during the period covered by this study. The second, and more important, reason for this omission is that the narratives concerning the Syrian Fathers all concern Kartli and it is in Kartli that we have a partial archaeological record of some Syrian occupation from the last centuries BCE onwards into the earliest centuries of the Common Era. Add to these factors the current impossibility of conducting fieldwork in Abkhazia alluded to above, and it becomes clear why it was most sensible to concentrate this research on Kartli.

The one exception to this decision is the inclusion of a substantial amount of information relating to Svaneti; this is because despite the fact that the earliest churches in the region only date back to the ninth century, Svaneti's role as the treasury of the Georgian Kingdoms over the centuries has meant that an extraordinary array of early liturgical objects has been gathered there and a number of these items are believed to have had direct, or at least hypothetical, links to Syria. Similar items have also been discovered elsewhere in western Georgia, notably around Kutaisi and, more recently, in Adjara ${ }^{11}$ making it

9 See the various articles by Philip Kohl on this subject listed in the bibliography for further information on this subject.

10 The figure of $20 \%$ of Georgia being occupied by Russia is often bandied about in the media and popular literature relating to the Georgian-Russian war of 2008. For a legal consideration of why this figure is accurate see Natia Kalandarishvili-Mueller's article on the blog of the European Journal of International Law http://www.ejiltalk.org/on-the-occasion-of-the -five-year-anniversary-of-the-russian-georgian-war-is-georgia-occupied/ (Accessed 26.01.2017).

11 Pers.comm. Elene Kavlelashvili, Senior Curator of the Treasury of the Shalva Amiranashvili Museum of Art, Tbilisi. 
seem prudent to include portable objects of possible Syrian origin from western Georgia in this study. The central and eastern mountain regions peopled by the Khevsurs and the Tush are considered in this work as peripheral cultures that may or may not have had influence on lowland society, as they were pagan until the middle ages and indeed in many respects are not believed to ever have been completely Christianised; certainly there are few churches in their mountains and they do not boast the strong Christian heritage of the Svans.

As the geo-political situation of the Middle East and the Caucasus seems unlikely to change radically towards peace in the near future, scholars must accommodate these shifting boundaries, but be honest about the impact that the current political situation has on their research; this will inevitably cause gaps in our knowledge and facilitate oversights. It is better to acknowledge this at the outset than to be accused of knowingly presenting a partial view of the situation by seeking to appear knowledgeable about regions and monuments that are currently inaccessible. Therefore it must be understood that this monograph relies on extensive fieldwork carried out in Syria between 1997 and 2010, after which the Syrian civil war made further visits impossible. After fleeting visits to Georgia in 2005 and 2006, the fieldwork for the Georgian section of the research was undertaken from 2013 onwards. Last but not least, save for a brief visit in 1997, the fieldwork on Eastern Asia Minor dates from 2012.

Bearing this in mind, the reader will no doubt have surmised by this point that the writer is coming at this project from a background specialising in the evolution of the early Syrian Church, in terms of both material culture and ecclesiastical and liturgical history. Therefore the Caucasian material marks a significant new direction of research and the debates surrounding the PostSoviet states of the region proved to be astonishingly vicious and partial, even for somebody used to negotiating the contested Judaeo-Christian heritage of the Levant. This fact is noted here in the full recognition that there will be many who disagree with the conclusions reached in this volume, some no doubt for valid academic reasons, but others due to a strongly partial nationalistic and doctrinal ideal. ${ }^{12}$ Whilst fully cognisant of the debates of the Council of Chalcedon and the brutal repercussions of that meeting in 451 for the unity of the

12 In May 2013 I was a participant in the Fifth International Symposium of the Georgian Orthodox Church on the "Tradition of Theotokos' Adoration in the Orthodox Church". Shortly before I left for Tbilisi I was told that, despite being an invited delegate, they were not allowing me to deliver the paper that I had submitted. I later discovered that I was prevented from speaking because my paper referred to both Chalcedonian and nonChalcedonian visual images of the Theotokos in Syria and this discussion of 'heretical' imagery was deemed unacceptable. 
Church ever since, the writer does not view either side of this schism as essentially 'right' or 'wrong' and as such does not pursue a doctrinal agenda in the work that follows.

Complex as it was to define the geographical parameters of this monograph, a similar question arose with regards to the question of the chronological span of this work. Late antiquity is a notoriously nebulous term that has been used for dates as early as the second century CE up until as late as the ninth century according to the varying geographical locations or disciplines under discussion. What is clear is that late antiquity is the correct term in this instance; the milieu that we shall be exploring was emphatically on the fringes of, and often beyond the reach of, the Byzantine Empire. At the same time it was influenced by, and often subject to, the Persian Empire of the Parthians and their successors the Sassanian dynasty. Despite this Kartli and Syro-Mesopotamia maintained their own languages, literary and material cultures and were never assimilated fully into either of the world empires that sought to subjugate them. Bearing these factors in mind it seems, to this writer at least, that late antiquity in this context began in the first half of the fourth century CE with the Peace of Constantine and ended at some point in the first two or three decades of the seventh century, when Georgia entered the Chalcedonian fold and the great Arab expansion began to redraw the world's maps.

Therefore, although there will be some contextualisation of the events that led to the spread of Christianity in the fourth century and the architecture discussed will include some monuments that were constructed as late as the mid to late seventh century, this book will define late antiquity in this instance as running from the fourth to seventh centuries. This is by no means intended to suggest that everything changes dramatically at this point; the narrative that argued for a cataclysmic social collapse in the seventh century has long been discredited, ${ }^{13}$ but at the same time the rise of Islam and the crystallization of the battlelines between the Chalcedonians and their non-Chalcedonian opponents suggest a suitable point at which to end this work.

13 See for example Geyer, Bernard, 'Expansion and Decline of Syria's Arid Margin', The Arab World Geographer, 5/2 (2002), pp. 73-84 for an argument of continuity of culture and population expansion within a changing settlement pattern in seventh century Syria. This will also be discussed in more detail in Chapter 2. 